\title{
Malign kemik tümörlerinin genel özellikleri
}

\section{Common features of malignant bone tumors}

\author{
Şenol Bekmez¹, Mehmet Ayvaz \\ ${ }^{1}$ Dr. Sami Ulus Eğitim ve Araştırma Hastanesi, Ortopedi ve Travmatoloji Bölümü, Ankara \\ ${ }^{2}$ Hacettepe Üniversitesi Tıp Fakültesi, Ortopedi ve Travmatoloji Anabilim Dalı, Ankara
}

\begin{abstract}
Malign kemik tümörleri insan vücudundaki tüm kanserlerin sadece küçük bir kısmını oluşturmaktadır. Nadir görülmelerinin yanında klinik özellikleri ve biyolojk davranışlarında çeşitlilik bulunmaktadır. Metastatik kemik tümörleri, primer malign kemik tümörlerine oranla çok daha sık görülmektedir. Az sayıda ortopedist ve belirli merkezler malign kemik tümörleri konusunda geniş tecrübeye sahiptir. Ortopedik onkoloji ile uğraşmayan cerrahların da en azından malign kemik tümörü şüphesi oluşturan belirti ve bulguları tanıması, hatalı ve yanlış tedaviden kaçınarak vakit kaybetmeden hastayı uygun merkezlere yönlendirmesi gerekmektedir. Malign kemik tümörlerinin kendine özgü klinik, radyolojik ve laboratuvar bulguları vardır. En önemli klinik belirti, özellikle istirahatte ortaya çıkan veya geceleri şiddetlenen ağrıdır. Şişlik ve eklem hareketlerinde azalma ise en önemli klinik bulgudur. Kas iskelet tümörü şüphesi bulunan olgulara her zaman standart bir yaklaşım uygulanamaz. Birçok kemik tümörünün kendine has radyolojik görüntüleme bulgusu tanımlanmıştır. Kas iskelet tümörlerinde en uygun bakım multidisipliner yaklaşımla sağlanabilmektedir. Patolog, radyolog, radyasyon onkolog, medikal onkolog ve vasküler cerrahtan oluşan medikal ekibin vazgeçilmez bir üyesi de ortopedik cerrahtır. Malign kemik tümörü şüphesi olan olgulara yaklaşımda uygun evrelendirme ve iyi planlanmış bir biyopsi hayati önem taşır.
\end{abstract}

Anahtar sözcükler: malign; kemik tümörleri; tanı
Malignant bone tumors compose a small percentage of all malign tumors in the human body. They form miscellaneous clinic and biologic characteristics even though they are quite rare. Metastatic bone tumors are much more common than the primary bone malignancies. Only certain orthopedic centers and orthopedists have broad experience about malignant bone tumors. However orthopedic surgeons in non-oncologic practice should recognize the signs and symptoms suggesting malignant bone tumors, avoid delayed and improper treatment approaches, and refer the patient to an appropriate oncologic center. Malignant bone tumors have characteristic clinic, radiologic and laboratory features. The most important symptom is pain while resting or increased night pain. Swelling and decrease in range of motion is the most common clinical sign. There is no common clinical algorithm suitable for all bone malignancies. Many of the malignant bone tumors have their own specific radiologic signs. The best can be provided by multidisciplinary approach. Orthopedic surgeon is a vital member of the medical team composed by pathologist, radiologist, radiation oncologist, medical oncologist and vascular surgeon. Proper staging and a well-planned biopsy is imperative for the approach in patients with suggested malignant bone tumors.

Key words: malignant; bone neoplasms; diagnosis
K emiğin primer malign tümörleri kemik dokusundan köken alır ve genel olarak metastazlara göre daha nadir görülür. Primer kemik tümörleri tüm neoplazmların yaklaşık \%0,2'sini oluşturur. ${ }^{[1,3,4]}$ Amerika Birleşik devletlerinde primer malign kemik tümörlerine bağlı mortalite yaklaşık milyonda dörttür. ${ }^{[1,2,5]}$ Tümörün tipine göre çocukluk, adolesan ve yaşlılık dönemlerinde tepe insidans yaşları değişkenlik gösterir. Ayrıca lokal rekürrens veya uzak metastaz davranışları da tümörün tipine göre değişir.
Primer malign kemik tümörleri için tanımlamış bazı risk etmenleri arasında radyoterapi, arsenik ve vinil klorid gibi kimyasallara maruziyet, kronik irritasyon, nörofibromatozis, Paget hastalığı, kemik infarktları, genetik kanser sendromları (Li-Fraumeni sendromu, retinoblastoma) sayılabilir. Ancak hastaların çoğunda etiyolojik bir etmen saptanamaz.

Sarkomlar embriyonik olarak mesodermal orijinden köken alır. Karsinomlara bağıı kemik metastazları ise primer kemik tümörlerine oranla çok daha sık görülür.

- İletişim adresi: Doç. Dr. Mehmet Ayvaz, Hacettepe Üniversitesi Tıp Fakültesi, Ortopedi ve Travmatoloji Anabilim Dalı, Sıhhiye, Ankara Tel: 0312 - 3051209 e-posta: mehmetayvaz@gmail.com

- Gelis tarihi: 17 Haziran 2014 Kabul tarihi: 17 Haziran 2014 
Tüm dünyada kanser insidansının giderek artması ve yeni tedavi modaliteleriyle kanser hastalarının beklenen yaşam sürelerinin artması gibi nedenlerle kemik metastaz insidansı giderek artmaktadır. ${ }^{[6]}$ Karsinom metastazlarının en sık üçüncü hedefi akciğer ve karaciğerden sonra kemikler olup, kemik kaynaklı ağrı hastaların geliş semptomu olabilmektedir. Metastatik hastalığı bulunan tüm kanser olgularının yaklaşık \%60-84'ünde kemik metastazı bulunduğu bilinmektedir. ${ }^{[7]}$ Hemen tüm malign tümörler kemiğe metastaz yapabilse de meme, akciğer, prostat, böbrek ve tiroid kanserleri en sık kemik metastazı yapan tümörlerdir.

\section{BIYOLOJiK DAVRANIŞ}

\section{Primer malign kemik tümörleri}

Primer malign kemik tümörleri, lokal agresif davranışları, rekürrens ve metastaz eğilimine göre derecelendirilir. Bu derecelendirme temel olarak sellülarite, mitoz sayısı ve histolojik büyüme paterni baz alınarak yapılır. Buna göre tümörler düşük dereceli ve yüksek dereceli olarak sınıflandırılır. Malign kemik tümörlerinin sergilediği biyolojik davranış iyi tanımlanmıştır. Kemik sarkomları genelde sentrifugal olarak gelişen, periferi en az matürite gösteren solid bir kitle oluşturur.
Tümör dokusunu çevreleyen ve psödokapsül olarak da adlandırılan reaktif bir zon tarafından çevrelenir. Bu reaktif zon, fibrovasküler yapılar, inflamatuvar komponent ve çevreleyen normal dokulardan meydana gelir. Reaktif zonun kalınlığı tümörün histolojik yapısı ve tümörün derecesi tarafından belirlenir. Yüksek dereceli sarkomların tümör tarafindan invaze edilmiş belirsiz sınırlı bir reaktif zonu bulunur. Malign bir tümörün psödokapsülü aşarak aynı anatomik kompartmanda oluşturduğu lezyonlara 'skip metastaz' adı verilir. ${ }^{[8]}$ Skip metastaz kavramı, temiz cerrahi sınırlarla çıkartılan bir olguda lokal rekürrensin oluşabilmesini açıklamaktadır. Psödokapsül içerisindeki tümor yayılımı ise 'satellit lezyon' olarak adlandırılır.

Malign kemik tümörlerinin lokal yayılımı, çevreleyen doğal bariyerlerden etkilenir. Genellikle sarkomlar dahil oldukları anatomik kompartman içerisinde en az dirençle karşılaştıkları yolda ilerler. Daha ileri evrelerde tümör mevcut kompartmanın sınırlarını invaze ederek komşu kompartmana yayılır (Şekil 1). Eklem kıkırdağının tümöral invazyonu ise nadirdir ve genellikle patolojik kırıkları takiben oluşur.

Malign kemik tümörlerinin metastatik yayılımı genellikle hematojen yolla olur. Ekstremite sarkomları erken
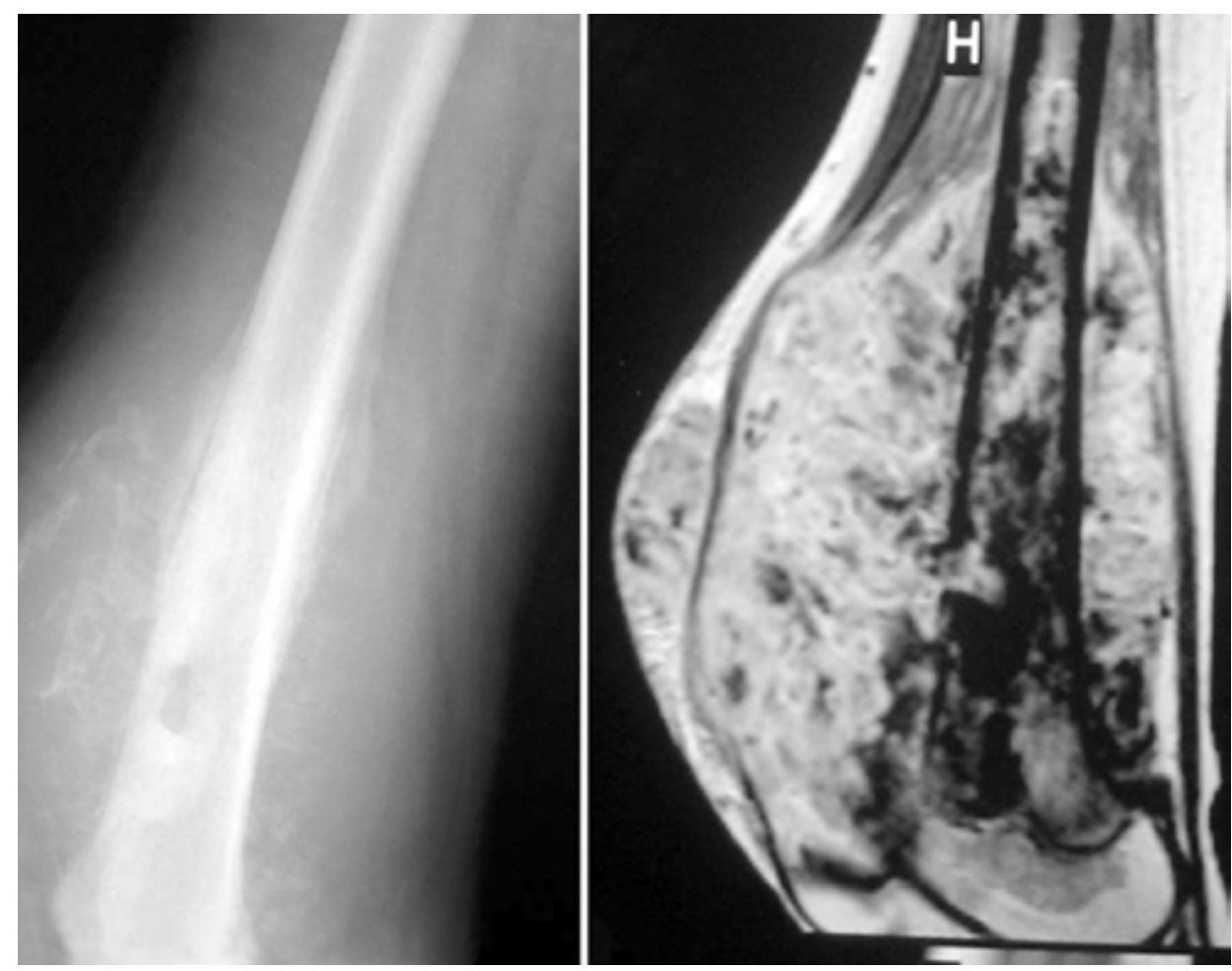

Şekil 1. On üç yaşında kız hastanın sağ femur distal yerleşimli malign kemik tümörü. Manyetik rezonans görüntülemede yumuşak doku ve cilt invazyonu görülebilmektedir. 
dönemde akciğerlere, ilerleyen evrelerde ise diğer kemiklere yayılım gösterir. ${ }^{\left[{ }^{[9]}\right.}$ Düşük dereceli sarkomlarda metastaz oranı \%15'ler civarında iken, yüksek dereceli sarkomlarda belirgin derecede yüksek metastaz oranları mevcuttur. Yüksek evreli osteosarkomlarda prezentasyon esnasında \%80'lere varan mikrometastatik akciğer yayılımı bildirilmiştir. Bu nedenle bu gibi olgularda kür ancak cerrahiye adjuvan sistemik kemoterapi ile sağlanabilir.

\section{Metastatik kemik lezyonları}

Metastatik kemik lezyonlarının biyolojik davranışları köken aldıkları primer hastalığa göre değişir. Akciğer, tiroid, böbrek ve kolon kanserlerinin metastatik lezyonları kemiğin belirli bir bölgesinde osteolitik kemik yıkımına neden olur.

Prostat, mesane ve mide kanserleri metastazlarında ise kanser yayılımına karşılık yeni kemik oluşumuyla karakterize osteoblastik yanıt meydana gelir. Meme kanseri metastazında ise kanser hücrelerinin salgıladığı farklı etmenlere farklı cevap oluşturan mikst osteoblastik ve osteolitik aktivite meydana gelir.

\section{TANI}

Malign kemik tümörlerinde tanı genelde hasta veya hekime bağı nedenlerle gecikmeli olarak konur. Bu durum, kısmen, malign kemik tümörlerinin nispeten nadir görülmesi ile açıklanabilir. Ayrıca hastalığın prezentasyonu sinsi başlangıçlı olabilmektedir. Özellikle pelvis yerleşimli tümörlerin ekstremiteye göre geç bulgu vermeleri nedeniyle tanısında gecikmeler olabildiği ve kötü prognozlu olduğu bilinir. Bu nedenle uygun olmayan ve eksik tedavilerin uygulanması hem tanıyı geciktirebilmekte, hem de beklenen sağkalımı olumsuz etkileyebilmektedir.

Malign kemik tümörlerinde öykü, fizik muayene ve röntgen görüntülemeleri birleştirildiğinde tüm olguların \%80'inden fazlasında tanı koydurucudur.

\section{Öykü ve fizik muayene}

Kas-iskelet sistemi tümörü olan bir hastanın başvuru şikayeti genellikle ağrıdır. Ancak hasta, ele gelen kitle veya başka amaçlarla çekilen röntgenlerde tespit edilen anormal radyolojik görüntüyle de başvurabilir. Ağrı ilk başlarda sadece aktivite ile ilişkili olabilir. Ancak malign kemik tümörü bulunan olgularda zamanla dinlenme esnasında ve geceleri de devam eden ilerleyici bir ağrı tarif edilir.

Fizik muayene, semptomun olduğu bölgenin değerlendirilmesi ile birlikte mutlaka sistemik değerlendirmeyi de içermelidir. Eğer bir kitle tespit edildiyse, yeri, boyutları, sınırları, kıvamı, mobilizasyonu, ısı artışı ve hassasiyeti belirlenmelidir. Ayrıca eşlik eden kas atrofisi not edilmeli, tutulan ekstremitenin nörolojik muayenesi ve vasküler değerlendirmesi de yapılmalıdır. Her ne kadar sarkomlarda lenf nodu metastazı sık görülmese de lenf nodu muayenesi de yapılmalıdır.

\section{Radyolojik değerlendirme}

Malign kemik tümörü şüphesi olan tüm olgular mutlaka ilk olarak röntgen ile değerlendirilmelidir. Özellikle ekstremite tümörlerinde kemiğin trabeküler yapısındaki bozulmalar erken teşhis edilebilmekte olup, pelvis ve omurga tümörlerinde, derin yerleşimleri nedeniyle, tümör büyük hacimlere ulaşmadan röntgen görüntülemeleri ile tanı konulamamaktadır. Röntgen değerlendirmesinde öncelikle lezyonun yeri tespit edilmelidir. Bazı spesifik tümörlerin kemikte karakteristik tutulum bölgeleri vardır. Ewing sarkom ve malign fibröz histiyositom daha çok diyafizer tutulum gösterirken, osteosarkom ve kondrosarkomda sıklıkla metafizer bölge tutulur. Metastatik lezyonlar ise daha çok vertebra korpusunda ve uzun kemiklerin proksimalinde metafizodiyafizer bileşkede yerleşim gösterir. Sakrumda yerleşim gösteren kordoma da klasik bir örnektir.

Kemik lezyonlarının radyografik incelemesinde bazı önemli noktalar bulunmaktadır. Lezyon 'nerede', 'içeriği nedir', 'kemikte ne gibi değişikliklere yol açmıştır' ve 'kemik lezyona ne yanıt vermiştir' gibi soruların karşılığı verilebilmelidir. Malign kemik lezyonlarında genellikle tümöral doku çok hızlı bir şekilde sağlıklı kemik dokusu ile yer değiştirdiği için, lezyonu çevreleyen bir sınır görülemez. Bu reaksiyon radyolojik olarak 'güve yeniğg' veya 'permeatif patern' olarak tanımlanır. Bu lezyonlar kortekste belirgin destrüksiyona yol açarak yumuşak dokulara yayılabilir ve patolojik kırık oluşturabilir. Kortikal destrüksiyon sonrası subperiosteal bölgeye ulaşan lezyon, periosteal yeni kemik oluşumunu tetikler. Periost reaksiyonunun tipi de lezyonun karakteri hakkında fikir verir. Hızlı büyüyen tümörler, periosteal kemik gelişimi için yeterli zaman bırakmadığı için sürekli olmayan bir periost reaksiyonu oluşturur. Sonuçta malign kemik lezyonlarında radyolojik olarak Codman üçgeni, soğan zarı veya güneş patlaması tarzında periost reaksiyonları meydana gelir (Şekil 2).

Metastatik kemik lezyonlarında ise osteolitik veya osteoblastik aktiviteye göre röntgen bulguları değişiklik gösterir. Özellikle metastatik lezyonlarda birden çok iskelet tutulum bölgesi olabileceğinden, rutin kemik taraması önerilir.

Kemik destrüksiyonunu en iyi tespit eden görüntüleme yöntemi bilgisayarlı tomografi (BT)'dir. Ayrıca pulmoner metastazların değerlendirilmesi de BT ile yapılır. 


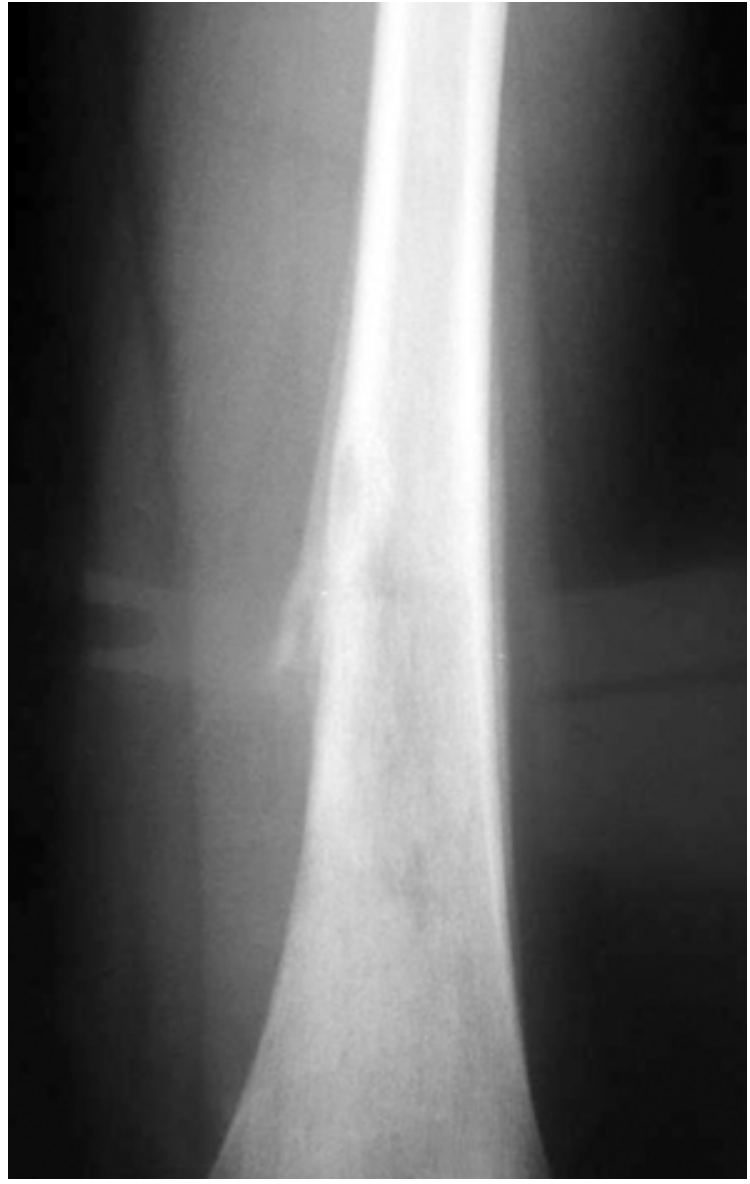

Şekil 2. On beş yaşında erkek hastanın femur distalinde osteosarkoma bağlı 'Codman üçgeni' periost reaksiyonu görülmektedir.

Tümörün intramedüller ve ekstraosseöz yumuşak doku yayılımını en iyi değerlendiren yöntem ise manyetik rezonans (MR) görüntülemedir. MR görüntüleme bazı tümörlerde spesifik tanı koydurabilse de çoğu tümör için MR bulguları nonspesifik olup, benign-malign ayırımı çoğu zaman yapılamaz. BT ve MR görüntülemenin her üç planda görüntüleme sağlaması ve kontrastla görüntü kalitesinin arttırılabilmesi gibi başka avantajları da vardır. Kemik sintigrafisinin malign kemik tümörlerinde günümüzde daha çok metastataz varlığının veya poliostotik tutulumlu hatalığın tespitinde yeri vardır. Anjiyografi ise tümör dokusu ile majör vasküler yapılar arasındaki ilişkinin ve tümör vaskülaritesinin değerlendirilmesinde kullanılır.

\section{Laboratuvar testleri}

Malign kemik tümörlerinin tanısında kullanılan diğer bir tanısal yöntem de laboratuvar testleridir. Tam kan sayımı, hematojen kaynaklı tümörlerin tanısında yardımcıdır. Artmış lökositoz ve eritrosit sedimentasyon hızı genelde enfeksiyon belirteci olsa da malign kemik tümörlerinde de belirgin bir şekilde yükselir. Serum protein elektroforezi özellikle multipl miyelom tanısında kullanılır. Alkalen fosfataz ve kalsiyum düzeyleri Paget hastalığı ve metastatik kemik tümörleri gibi birçok hastalık varlığında nonspesifik olarak yükselir. Multipl miyelomlu hastalarda anemi ve serum ve idrar protein elektroforez bulguları mevcuttur. PSA gibi tümör belirteçlerinin kan düzeyleri de spesifik tümörlerin varlığında yükselmektedir.

\section{Biyopsi}

Malign kemik tümörlerinde kural olarak biyopsi evrelemenin son basamağını oluşturmaktadır. Biyopsi tedavinin de ilk basamağını oluşturduğu için kesin tedavinin yapılacağı, deneyimli bir merkezde yapılmalıdır. Klinik ve radyolojik incelemenin ardından lezyonun iyi ya da kötü huylu olduğuna dair genel bir fikir oluşmuş olmalıdır. Birden çok bölgede tutulum gösteren tümörlerde biyopsi materyalinin cerrahi olarak en kolay ulaşılabilen bölgeden alınması önerilir. Biyopsi seçenekleri ince iğne aspirasyonu, trokar veya açık biyopsidir. Kas iskelet sistemi tümörlerinde biyopsi, onkolojik prensiplere uygun bir şekilde, çevre yumuşak dokulara çok az kontaminasyonla, eklem koruyucu cerrahiye en iyi olanağı sağlayacak şekilde yapılmalıdır. Kemik lezyonu saptanan tüm olgular potansiyel birer ekstremite koruyucu cerrahi adayı olduklarından, gereksiz veya genel prensiplere uyulmadan yapılan biyopsilerin ekstremitenin veya hastanın kaybı ile sonuçlanabileceği akılda tutulmalıdır. ${ }^{[10]}$

\section{Orijini bilinmeyen metastaza yaklaşım}

Kırk yaşından büyük bir hastada yeni ortaya çıkan ağrılı bir kemik lezyonu varlığında, bilinen bir kanser öyküsü olmasa bile ilk olarak akla gelmesi gereken tanılar multipl miyelom veya metastaz olmalıdır. Kemik metastazı için en olası kaynaklar prostat ve meme kanseridir. Ancak bilinen primer tümörü olmayan hastalarda en olası tanılar akciğer ve renal karsinomlardır.

Bu tür hastalarda laboratuvar testi olarak tam kan sayımı, sedimentasyon hızı, elektrolitler, karaciğer enzimleri, alkalen fosfataz, serum protein elektroforezi ve PSA düzeylerine bakılmalıdır. Semptomatik olan bölge ve akciğer röntgenleri istenmelidir. Tüm vücut kemik sintigrafisi olası diğer kemik tutulum bölgelerini gösterir. Ayrıca toraks, abdomen ve pelvisin BT görüntülemesi istenmelidir. Bu tanısal algoritma ile primeri bilinmeyen metastazlarda \%85 oranında primer tümörün tespit edilebildiği bildirilmiştir. ${ }^{[11,12]}$ 


\section{EVRELEME}

Tümörleri gruplandırmak veya tedavi şemalarını belirlemek amacıyla ayrıca evreleme sistemleri kullanılmaktadır. Kemik tümörlerinde tümörün derecesini, lokal yayılımını ve metastatik yayılımı bir arada değerlendiren Enneking ve arkadaşlarının tanımladığı evreleme sistemi kullanılır (Tablo 1). ${ }^{[13]}$ Ayrıca lenf nodu metastazı ve skip metastaz varlığını değerlendiren American Joint Comitee on Cancer evreleme sistemi de tanımlanmıştır (Tablo 2). ${ }^{[14,15]}$

Farklı tipteki tümörler, histolojik görünümleri, köken aldıkları doku/hücre veya ürettikleri stroma baz alınarak sınıflandırılır. Buna göre malign kemik tümörleri, kıkırdak tümörleri, osteojenik tümörler, fibrojenik tümörler, fibrohistiyositik tümörler, Ewing sarkomu, hematopoietik tümörler, dev hücreli tümör, notokord kökenli tümörler, düz kas kökenli tümörler, lipojenik tümörler ve karışık tümörler tanımlanmıştır. ${ }^{[5]}$

\section{GENEL TEDAVI PRENSIPLERi}

Malign kemik tümörlerinde geleneksel tedavi yöntemi ampütasyon olarak kabul edilmekle beraber, neoadjuvan kemoterapi, radyoterapi ve cerrahi tekniklerdeki ilerlemeler sayesinde ekstremite koruyucu cerrahi ile de başarılı sonuçlar elde edilebildiği gösterilmiştir.
Tümör cerrahisi prensiplerine göre tanımlanmış dört çeşit cerrahi rezeksiyon seçeneği vardır. Burada belirleyici etken cerrahi diseksiyon sınırları ile tümör dokusu ve psödokapsül arasındaki ilişkidir. ${ }^{[16]}$ Rezeksiyon sınırı tümör dokusunun içinden geçiyorsa intralezyonel olarak adlandırılır. Marjinal rezeksiyonda cerrahi sınır psödokapsülden geçer; geniş rezeksiyonda ise cerrahi sınır tüm planları içerir, tümör, tüm psödokapsül ve bir miktar sağlıklı dokuyu içerecek şekilde çıkartılır. Malign kemik tümörlerinde başarılı bir tedavi için amaçlanan rezeksiyon şekli genellikle geniş rezeksiyondur. Tümörle birlikte yer aldığı kompartmanın tamamının çıkartılması radikal rezeksiyon olarak tanımlanır. Radikal rezeksiyonda skip metastaz olasılığı teorik olarak engellenmektedir. Tümörün tipine ve temiz cerrahi sınır elde edilebilmesine göre tedavi protokolüne adjuvan kemoterapi veya radyoterapi eklenebilir.

Metastatik kemik lezyonlarında ise, tek bölge tutulumu primer malign kemik tümörü gibi geniş rezeksiyonla tedavi edilir. Çoklu kemik tutulumunda ise palyatif tedavi yöntemleri uygulanır. Metastatik kemik tümörleri genel olarak radyoterapiye iyi yanıt verir. Patolojik kırık veya kırık riski bulunan olgularda ise internal tespit ve çimento ile güçlendirme gibi tedavi seçenekleri ön plandadır.

Tablo 1. Enneking evreleme sistemi

\begin{tabular}{lccc}
\hline Enneking Evresi & Derece & Lokal Yayılım & Uzak metastaz \\
\hline la & Düşük & Intrakompartmantal & - \\
lb & Düşük & Ekstrakompartmantal & - \\
Ila & Yüksek & Intrakompartmantal & - \\
Ilb & Yüksek & Ekstrakompartmantal & - \\
III & Yüksek & - & +
\end{tabular}

Tablo 2. AJCC evreleme sistemi

\begin{tabular}{lcccc}
\hline AJCC Evresi & Derece & Primer Tümör & Lenf nodu & Metastaz \\
\hline la & Düşük & Korteksi aşmayan & - & - \\
Ib & Düşük & Korteksi aşan & - & - \\
Ila & Yüksek & Korteksi aşmayan & - & - \\
IIb & Yüksek & Korteksi aşan & - & Skip metastaz \\
III & - & - & $-/+$ & Akciğer metastazı \\
IVa & - & $-/+$ & Akciğer dışı metastaz
\end{tabular}




\section{KAYNAKLAR}

1. Ries LAG, Smith MA, Gurney JG, Linet M, Tamra T, Young JL, Bunin GR (eds). Cancer Incidence and Survival among Children and Adolescents: United States SEER Program 1975-1995, National Cancer Institute, SEER Program. NIH Pub. No. 99-4649. Bethesda, MD, 1999.

2. Devesa SS, Silverman DT, Young JL Jr, Pollack ES, Brown CC, Horm JW, Percy CL, Myers MH, McKay FW, Fraumeni JF Jr. Cancer incidence and mortality trends among whites in the United States, 1947-84. J Natl Cancer Inst 1987; 79(4):701-70.

3. Unni KK, Inwards CY. Dahlin's Bone Tumors: General Aspects and Data on 10, 165 Cases. Philadelphia, PA: Lippincott Williams \& Wilkins; 2010.

4. Blackwell JB, Threlfall TJ, McCaul KA. Primary malignant bone tumours in Western Australia, 1972-1996. Pathology 2005;37(4):278-83.

5. Mulder JD, Schutte HE, Kroon HM, Taconis WK. Radiologic atlas of bone tumors, 2nd ed. Amsterdam: Elsevier; 1993.

6. Bagi CM. Targeting of therapeutic agents to bone to treat metastatic cancer. Adv Drug Deliv Rev 2005;57(7):995-1010.

7. Varadhachary GR, Abbruzzese JL, Lenzi R. Diagnostic strategies for unknown primary cancer. Cancer 2004;100(9):1776-85.

8. Malawer MM, Dunham WK. Skip metastases in osteosarcoma: recent experience. J Surg Oncol 1983;22(4):236-45.
9. Burk CD, Belasco JB, O’Neill JA Jr, Lange B. Pulmonary metastases and bone sarcomas. Surgical removal of lesions appearing after adjuvant chemotherapy. Clin Orthop Relat Res 1991;(262):88-92.

10. Mankin HJ, Mankin CJ, Simon MA. The hazards of the biopsy, revisited. Members of the Musculoskeletal Tumor Society. J Bone Joint Surg Am 1996;78(5):656-63.

11. Rougraff BT, Kneisl JS, Simon MA. Skeletal metastases of unknown origin. A prospective study of a diagnostic strategy. J Bone Joint Surg Am 1993;75(9):1276-81.

12. Katagiri $H$, Takahashi $M$, Inagaki J, Sugiura $H$, Ito $S$, Iwata $H$. Determining the site of the primary cancer in patients with skeletal metastasis of unknown origin: a retrospective study. Cancer 1999;86(3):533-7.

13. Enneking WF, Spanier SS, Goodman MA. A system for the surgical staging of musculoskeletal sarcoma. 1980. Clin Orthop Relat Res 2003;(415):4-18.

14. Fletcher CDM, Unni KK, Mertens F. Pathology and Genetics of Tumours of Soft Tissue and Bone (IARC WHO Classification of Tumours).Lyon: IARC Press; 2002.

15. Greene FL, Page DL, Fleming ID, Fritz A, Balch CM, Haller DG. American Joint Committee on Cancer. AJCC Cancer Staging Manual, 6th ed. New York: Springer-Verlag; 2002.

16. Bell RS, O'Sullivan B, Liu FF, Powell J, Langer F, Fornasier VL, Cummings B, Miceli PN, Hawkins N, Quirt I, et al. The surgical margin in soft-tissue sarcoma. J Bone Joint Surg Am 1989;71(3):370-5. 